cussion meetings were arranged on such varied subjects as: "Road Traffic: Flow and Control"; "Government Responsibility in Industrial Research", "Hopes and Aims of the Intermational Geophysical Year" ; "Vital Statistics in Psychiatry"; and "The Visit of the Royal Society Delegation to the U.S.S.R:", but lack of funds curtailed the number of receptions. Nevertheless, overseas delegates to the Internationa] Congress on the Documentation of Applied Chemistry and to the Faraday Society Discussion on Nucleic Acids were entertained and receptions were arranged for representatives of the Academy of Sciences of the U.S.S.R. visiting Britain under the auspices of the Royal Society and the British Council, for Sir K. S. Krishnan, director of the National Physical Laboratory of India, and for members of the Bureau of the Intermational Council of Scientific Unions. The Overseas Science Students Association had a successful year. Although the Society now has nearly 2,700 members from sixty-four countries, it has been necessary to launch a further appeal for funds. An annual income of $£ 10,000$ a year would enable the Society to treble or quadruple the value of its work, which seems to have even greater potentialities at this juncture in international relations. Tribute is paid to the support and co-operation received from the scientific societies.

\section{Physiology and Pathology of the Kidney}

IN his introduction to "Physiology and Pathology of the Kidney", Prof. Robert Platt directs attention to the wide variety of scientific and medical disciplines brought together in the study of renal disease. This is borne out by the diversity of subjects involved in the sixteen summaries which constitute British Medical Bulletin, 13, No. 1, edited by Prof. Clifford Wilson (Pp. $x v+74+12$ plates. London: British Council, 1957. 20s. net). Appropriately, the first essay is on renal function in the new-born (by Prof. R. A. MeCance and Dr. E. M. Widdowson), and the last is one on the effects of old age on the kidney by Dr. G. C. Kennedy, who finds that over-nutrition produces lesions in rats which seem to represent premature senility. Three of the essays deal with potassium in relation to the kidney and three with hypertension. Urinary stone formation is discussed by Dr. M. G. MeGeown and Prof. G. M. Bull, and the influence of renal disease on bone by Dr. S. W. Stanbury. Perhaps the balance in these reviews seems weighted somewhat in favour of the pathology rather than the physiology of the kidney, but the diseased organ often furnishes a ready-made experiment which can throw light on normal function in man. Dr. H. Harris's article on renal amino-aciduria provides a case in point, for it shows how the three genetically determined disorders included under this title may help to explain tubular absorption in the normal kidney. This collection of reviews, which includes a good deal of hitherto unpublished experimental work, claims to present only a sample of the research now in progress on the kidney. It is to be followed by a similar review on the liver.

\section{Field Studies Council}

THE annual report of the Field Studies Council for 1955-56 (pp. $68+8$ plates. London : Field Studies Council, 1957) should give considerable satisfaction to all who wish to promote interest in field studies. With each of its four Centres recording a student attendance of well over 1,000 , the total attendances at all Centres in 1956 showed a considerable increase over the figures for the previous year. Most encouraging is that well over half the total number of visitors to the Centres came from schools; in itself, this is sufficient justification for their existence. Even more use could be made of the Centres, however, and to fill them during the 'off-season' months of May and June, in 1957 the Council is providing courses which should be specially suitable for pupils and teachers in secondary modern schools. To meet the increased pressure at the four existing Centres during the popular periods, a fifth Centre has been opened at Preston Montford in Shropshire. Like the others, it offers a variety of courses in 1957 which should cater for many differing. interests in natural history. The problem of finance has again caused great concern to the Council and, to resolve the difficulties so that it may plan solidly for the future, it has been decided to try to raise the sum of $£ 10,000$ by loans, subscriptions and donations. Copies of the Council's report and particulars of the appeal may be obtained from Mr. F. H. C. Butler, Ravensmead, Keston, Kent.

\section{Amino-acids in the Growth of Plant Embryos}

A. H. G. C. RuJven has investigated the value of glutamine and asparagine as nitrogen sources for the in vitro growth of embryos (Austral. J. Biol. Sci., 9, 511 ; 1956). A comparative study of twelve species was made. Subsequent to his earlier work on Capsella bursa-pastoris (L.) Moench., embryos of species from nine families, monocotyledons and dicotyledons, excised from young developing ovules, were grown in a 'sitting drop' culture. For each species, the embryonic growth in length was compared in a control medium, that is, without nitrogen, and in media containing $L$-glutamine and $L$-asparagine. In all cases the growth in glutamine was superior. Additional data on Capsella are presented which deal with the growth-concentration relationships of glutamine and asparagine. Glutamine increasingly stimulated growth up to $600 \mathrm{mgm}$./l. Asparagine stimulated growth at $10 \mathrm{mgm} . / \mathrm{l}$. but became inhibitory at higher concentrations. The inhibition of growth with asparagine (400 mgm./l.) was also found in Arabidopsis thaliana (L.) Heynh. and Reseda odorata L. However, at this concentration, asparagine proved stimulating in Sisymbrium orientale L., Cleome viscosa L., Medicago tribuloides Desr. and $M$. orbicularis All., in Anagallis arvensis L., Datura stramonium L., Chenopodium album L. and Allium cepa I.

Halidrys siliquosa : Haploid Member of the Fucales

IT has long been accepted-admittedly on very scanty evidence - that the Fucales (or Cyclosporeae) are diploid organisms, with no somatic alternation of generations, the brief haploid phase occurring between meiosis in the antheridium and oogonium and the fertilization of the ovum. In 1909 Yamanouchi demonstrated that the first nuclear divisions in the antheridia and oogonia of Fucus vesiculosus were meiotic. Since then there have been few further cytological investigations. In a recent study of the cytology of Halidrys siliquosa, B. L. Moss and E. Elliot (Ann. Bot., 21, 143; 1957) have made some interesting observations which suggest that the thallus of this brown seaweed is haploid, reduction division taking place immediately after the fertilization of the ovum. They record eight chromosomes in the vegetative cells of the thallus and in the developing antheridial and oogonial cells. No meiosis was 